\title{
Chemical Composition of Lick Soils and Functions of Soil Ingested by Common Warthogs (Phacochoerus africanus) in Dabena Valley Forest, Western Ethiopia
}

\author{
Alemayehu Edossa ${ }^{1,}$, , Afework Bekele ${ }^{2}$, Habte Jebessa Debella ${ }^{2}$ \\ ${ }^{1}$ Department of Biology, Adama Science and Technology University, Adama, Ethiopia \\ ${ }^{2}$ Department of Zoological Sciences, Addis Ababa University, Addis Ababa, Ethiopia \\ Email address: \\ alemayehuedossa19@gmail.com (A. Edossa), alemayehuedossa19@gmail.com (A. Edossa) \\ ${ }^{*}$ Corresponding author
}

\section{To cite this article:}

Alemayehu Edossa, Afework Bekele, Habte Jebessa Debella. Chemical Composition of Lick Soils and Functions of Soil Ingested by Common Warthogs (Phacochoerus africanus) in Dabena Valley Forest, Western Ethiopia. American Journal of Bioscience and Bioengineering. Vol. 9, No. 1, 2021, pp. 13-20. doi: 10.11648/j.bio.20210901.13

Received: December 18, 2020; Accepted: January 6, 2021; Published: March 22, 2021

\begin{abstract}
To identify chemical composition of lick soil and function of soil ingested by common warthogs (Phacochoerus africanus), the study was conducted in Gassi Controlled Area (GCHA); southwestern and in Haro Aba Diko Controlled Hunting Area (HADCHA) northeastern Dabena Valley Forest from May 2016 to June 2018. Top soil samples licked by common warthog were taken from $2.5 \mathrm{~cm}$ diameter, $20 \mathrm{~cm}$ deep soil cores, from five evenly spaced locations around the periphery of the central $60 \times 60 \mathrm{~m}$ grid in each feeding plot. Soil samples were dried under shade for one week and then kept at $28^{\circ} \mathrm{C}$ until analyzed. Samples were homogenized and sieved through $2 \mathrm{~mm}$ mesh. The mean proportion of organic carbon in Menjiko $(\mathrm{t}=5.21, \mathrm{df}=1, \mathrm{P}<0.01)$ and in Gimbicho $(\mathrm{t}=-4.08, \mathrm{df}=1, \mathrm{P}<\mathrm{P} 0.05)$ revealed significant variation between wet and dry seasons. The mean proportion of total nitrogen was lower in GCHA $(0.153 \pm 0.014)$ and higher in HADCHA $(0.206 \pm 0.014)$ during the dry season. Hence, they showed significant variation $(\mathrm{F} 1,14=7.06, \mathrm{P}<0.05)$ in the amount of total nitrogen. Mean sodium concentration in salt lick, common warthog ingested varied from $0.01 \pm 0.001 \mathrm{Na}$ meq $/ 100 \mathrm{~g}$ (Menjiko) to $0.08 \pm 0.006$ $\mathrm{meq} / 100 \mathrm{~g}$ (Dodeta) during the dry season. However, the study areas were insignificantly different $(\mathrm{F} 1,14=1.63, \mathrm{P}>0.05)$. Mean potassium concentration in salt lick common warthog ranged from $0.11 \pm 0.014 \mathrm{meq} / 100 \mathrm{~g}$ (Desa) to $0.246 \pm 0.01 \mathrm{meq} / 100 \mathrm{~g}$ (Robe) during the wet season in Dabena Valley Forest (DVF). Warthogs supplemented their forage intake by licking different mineral elements from the ground. Mineral lick also benefits the animals in regulating the state body equilibrium and defending pathogens invading the animal's body.
\end{abstract}

Keywords: Chemical Composition Common Warthog, Functions, Ingested, Lick Soils

\section{Introduction}

Common warthogs salt lick mostly in the morning and afternoon hours [20]. The greatest peaks in visits of such sites occur from December to February [6, 16, 25]. The peak periods visit lick site coincide with plant phenology (variable timing of plant growth and forage preferences) [17, 27]. The visitation periods associated with the increased physiological demands of growth, or weight regain, motivated by electrolyte loss related to stress of sudden changes in forage chemistry of the animal $[6,16,26,29]$. Common warthogs use wet (Figure 1) and dry licks (Figure 2) $[6,17,26]$. Wet lick is linked with the change in forage chemistry and the loss of sodium from sweat or urine is much more than other times of the year [26] and underground water springs [6]. Dry licks usually occur along streams or riverbeds because un weathered soluble elements are deposits above less firm layers, and become exposed by erosion as dry licks [6].

Salt licks contain high levels of essential minerals such as nitrogen, phosphorus, sodium, potassium, calcium and magnesium $[12,16,20,21]$. These essential minerals are lacking in the diets of animals $[14,16]$. Shortage of macro and micro elements are not necessarily result of inadequate dietary ingestion only, but rather of digestive disorders linked 
with spring forage alteration [6]. Hence, mammals of tropical savanna are obligated to supplement minerals from other sources to ensure enough nutrients in their diets $[20,21,26]$.

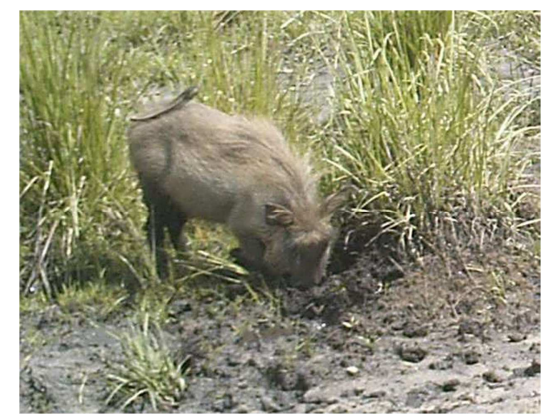

Figure 1. Common warthog drinking lick materials in the study area (Camera trap: Habta J. Debella, March 2018).

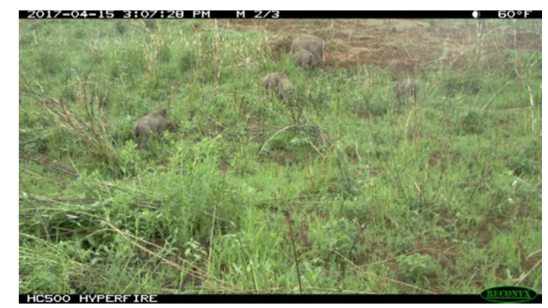

Figure 2. Common warthogs eating lick materials in HADCHA (Camera trap:: Alemayehu Edossa April, 2017).

\section{Materials and Methods}

\subsection{Description of the Study Areas}

Ethiopia is one of the East African countries rich in flora and fauna diversities. Common warthogs are widely distributed throughout DVF of western part of the country. To facilitate and manage the study, DVF was divided into two. The southwestern side of DVF was named GCHA and the northeastern side, HADCHA. The Dabena River borders the two. The vegetation type of the DVF was identified as Cumbretum- Terminalia, open grassland and riparian forest. DVF encompasses different medium sized and large mammalian species [1].

\subsubsection{Gassi Controlled Hunting Area (GCHA)}

Gassi Controlled Hunting Area (GCHA) is located in the Oromia Regional State, Buno Bedelle Administrative Zone. Most of the study sites lie in Meko and Dabohanna districts, along the Banks of the Dabena River. It is located approximately $600 \mathrm{~km}$ west of Addis Ababa. Gassi Controlled Hunting Areais situated in the southwestern part of Dabena Valley Forest (DVF), between $8^{\circ} 39^{\prime} 15^{\prime \prime}-8^{\circ} 52^{\prime}$ 30 " N latitude and $35^{\circ} 55^{\prime} 30^{\prime \prime}-36^{\circ} 7$ ' $15^{\prime \prime}$ E longitude. The elevation ranges from 1,538 to 1689 masl (Figure 3). Gassi and Miesso rivers drain in Dabena River. Dabena Valley Forest (DVF) is situated within the Didessa River sub-basin. Didessa River is the second catchment area of Abay basin next to Dabus, the largest drainage of the upper Blue Nile River Basin [4, 13]. Didessa and Dabus rivers drain the southwestern part of the basin, and contribute one third of the total flow of the Grand Ethiopian Renaissance Dam [11] which is the main sediment source of the Nile River [2]. Gassi controlled hunting area was demarcated as a controlled hunting area in 2007 with an estimated total area of 24,000 ha that includes Combretum-Terminalia woodland and riparian forest [1].

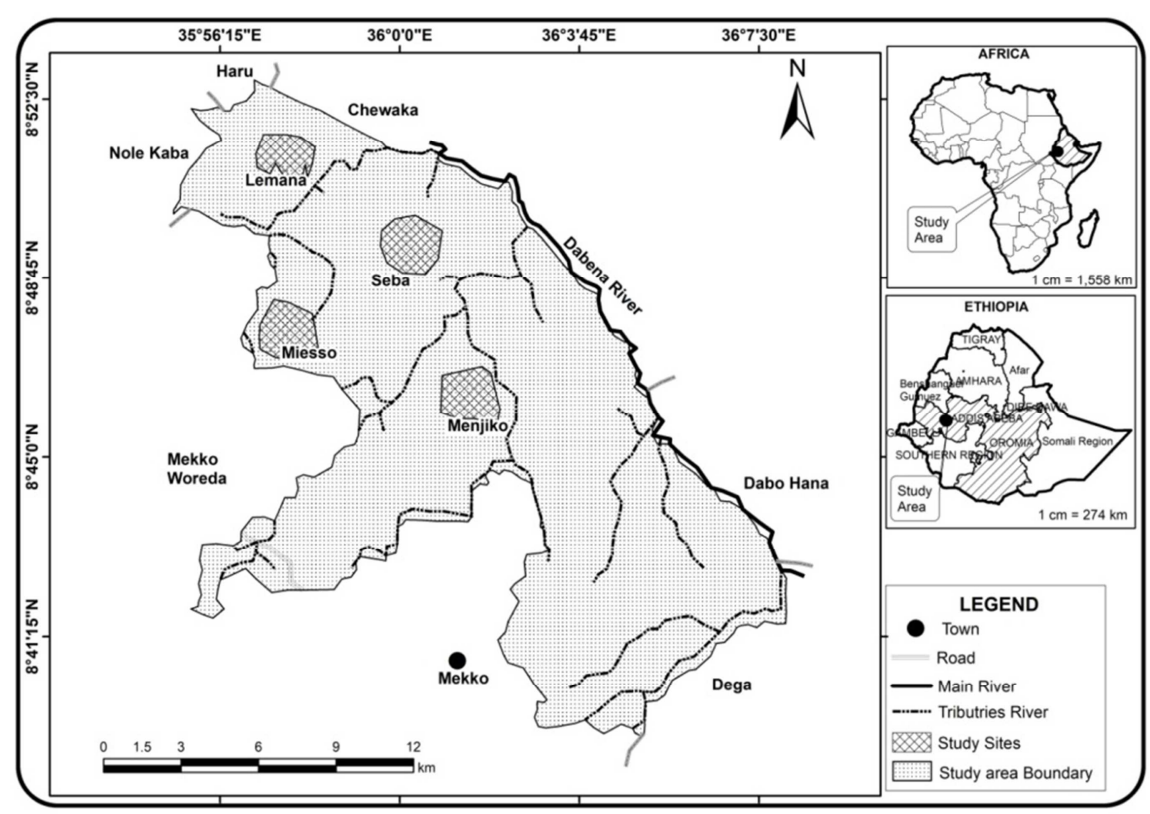

Figure 3. Location map of Gassi Controlled Hunting Area.

\subsubsection{Haro Aba Diko Controlled Hunting Area (HADCHA)}

Haro Aba Diko Controlled Hunting Area is located in the
Oromia Regional State, Buno Bedelle Administrative Zone of Ethiopia. It is approximately $550 \mathrm{~km}$ west of Addis Ababa on the southern side of Addis Ababa Nekemte-Gimbi road along 
the western lowland of the country. Haro Aba Diko Controlled Hunting Area is situated along the northeastern part of Dabena Valley Forest (DVF) between $8^{\circ} 35^{\prime} 20^{\prime \prime}$ $8^{\circ} 45^{\prime} 55^{\prime \prime} \mathrm{N}$ latitude and $36^{\circ} 15^{\prime} 45^{\prime \prime}-36^{\circ} 20^{\prime} 10^{\prime \prime} \mathrm{E}$ longitude. The elevation ranges from 1,646 to 1,720 masl (Figure 4).
HADCHA was demarcated in 2007 with an estimated total area of 53,841 ha that includes savanna woodland and riparian forest. It is one of the controlled hunting areas in the western Ethiopia that could be used as the future carbon sequestration center of the country [1].

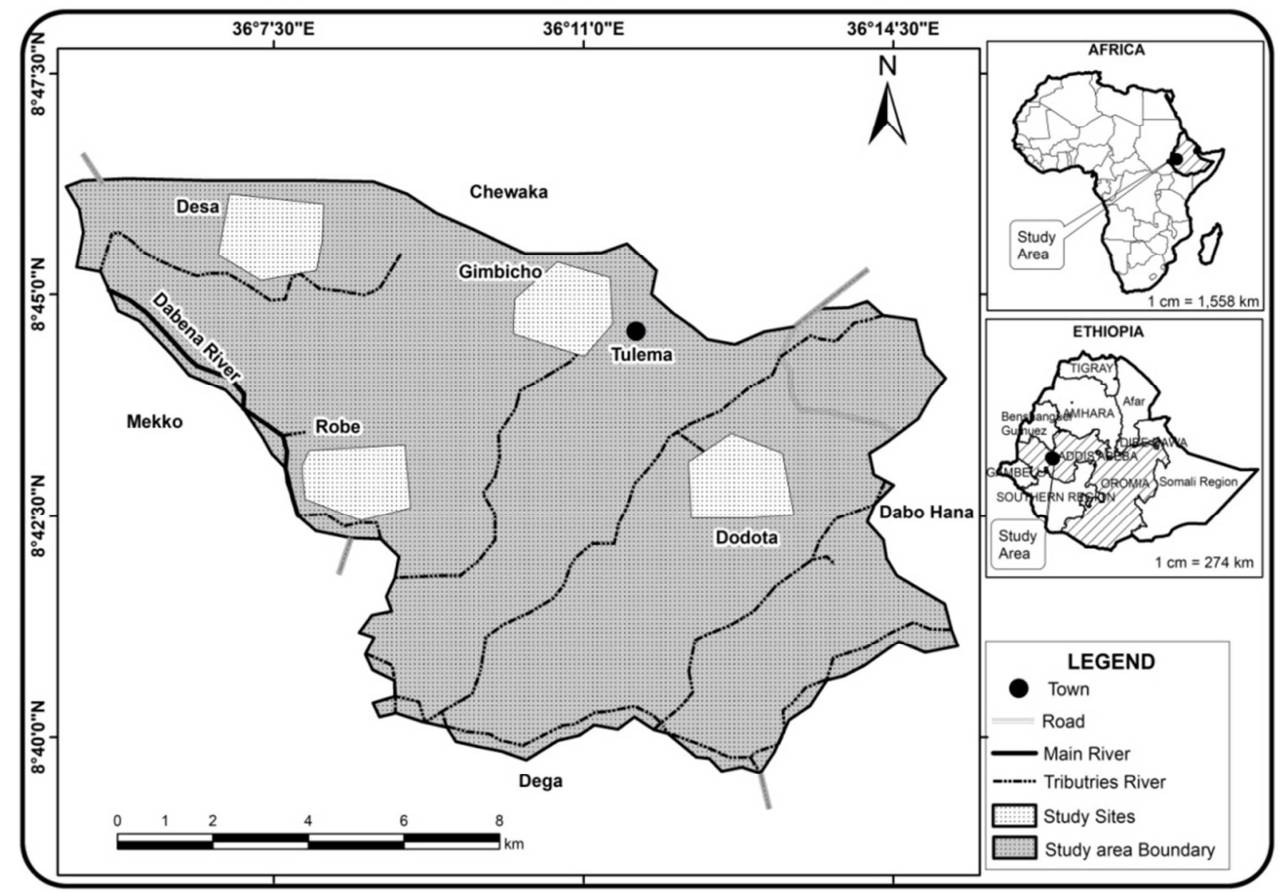

Figure 4. Location map of Haro Aba Diko Contolled Hunting Area.

\subsection{Methods}

Salt licking data were collected from eight randomly allocated study sites. These include: Robe, Desa, Gimbicho, and Dodeta sites from HADCHA and Menjiko, Seba, Messio and Lemana sites from GCHA. Top soil samples licked by common warthog were taken from $2.5 \mathrm{~cm}$ diameter, $20 \mathrm{~cm}$ deep soil cores, from five evenly spaced locations around the periphery of the central $60 \times 60 \mathrm{~m}$ grid in each feeding plot $[15,23]$. All samples from each feeding plot were pooled and thoroughly mixed for each study sites. A total of $32 \mathrm{~kg}$ soil samples were collected during the dry and wet seasons of 2017 and 2018 study periods. Soil collected from study plots were marked using GPS [8, 10, 34]. Soil samples were dried under shade for one week and then kept at $28^{\circ} \mathrm{C}$ until analyzed. Samples were homogenized and sieved through 2 mm mesh [3, 15, 30]. Soil samples were analyzed [33] at the Soil Laboratory of Holeta National Agricultural Research Center.

\subsection{Data Analyses}

Total $\mathrm{N}$ and $\mathrm{C}$ and nutrient content of $\mathrm{P}, \mathrm{Na}, \mathrm{K}, \mathrm{Ca}$, and $\mathrm{Mg}$ of soil samples ingested by warthogs were analyzed by inductively coupled plasma spectroscopy [3, 15, 20, 32]. One-way ANOVA was used to test the differences between the chemical properties of the geophagical soils of the study sites [20]. Chi-square was used to analyze seasonal differences of ingested soil and data of descriptive statistics were presented as mean $\pm \mathrm{SE}[20,25]$.

\section{Result}

The mean proportion of organic carbon (OC) in salt licked common warthogs ingested varied from $1.91 \pm 0.39$ (Gimbicho) to $2.92 \pm 0.89$ (Robe) during the wet season. On the other hand, it ranged from $1.8 \pm 0.54$ (Miesso) to $2.94 \pm 0.08$ (Desa) during the dry season. Seasonal mean proportion of organic carbon in Miesso $(\mathrm{t}=-0.22, \mathrm{df}=1, \mathrm{P}>$ $0.05)$, Seba $(\mathrm{t}=0.36, \mathrm{df}=1, \mathrm{P}>0.05)$, Lemana $(\mathrm{t}=-0.107, \mathrm{df}=1$, $\mathrm{P}>0.05)$, Robe $(\mathrm{t}=0.16, \mathrm{df}=1, \mathrm{P}>0.05)$, Desa $(\mathrm{t}=1.28, \mathrm{df}=1$, $\mathrm{P}>0.05)$ and in Dodeta $(\mathrm{t}=1.43, \mathrm{df}=1, \mathrm{P}>0.05)$ were not significantly different. In contrast, the mean proportion of organic carbon in Menjiko $(\mathrm{t}=5.21, \mathrm{df}=1, \mathrm{P}<0.01)$ and in Gimbicho $(\mathrm{t}=-4.08, \mathrm{df}=1, \mathrm{P}<0.05)$ revealed significant variation between wet and dry seasons (Table 1). The proportion of total nitrogen (TN) mean in salt lick common warthog ingested varied from $0.043 \pm 0.01$ (Desa) to $1.93 \pm 0.023$ (Seba) during the wet season. On the other hand, the proportion ranged from $0.125 \pm 0.014$ (Lemana) to $0.236 \pm 0.08$ (Desa) during the dry season. Seasonal mean proportion of total nitrogen in Miesso $(\mathrm{t}=-0.22, \mathrm{df}=1$, $\mathrm{P}>0.05)$, in Seba $(\mathrm{t}=-1.71, \mathrm{df}=1, \mathrm{P}>0.05)$, in Menjiko $(\mathrm{t}=1.69$, $\mathrm{df}=1, \mathrm{P}>0.05)$, in Robe $(\mathrm{t}=-0.75, \mathrm{df}=1, \mathrm{P}>0.05)$, in Gimbicho $(\mathrm{t}=-1.75, \mathrm{df}=1, \mathrm{P}>0.05)$ and in Dodeta $(\mathrm{t}=0.65, \mathrm{df}=1, \mathrm{P}>0.05)$ were not significantly different. In contrast, the mean proportion of total nitrogen in Lemana $(\mathrm{t}=3.08, \mathrm{df}=1, \mathrm{P}<0.05)$ 
and in Gimbicho $(\mathrm{t}=15.06, \mathrm{df}=1, \mathrm{P}<0.001)$ revealed significant variation between the wet and dry seasons (Table 1). The mean proportion $\mathrm{pH}$ in salt licking common warthog consumed varied from $4.8 \pm 0.005$ (Gimbicho) to $5.34 \pm 0.41$ (Dodeta) during the wet season. On the other hand, it was varied from $4.23 \pm 0.01$ (Robe) to $5.16 \pm 0.25$ (Desa) during the dry season.

Table 1. $M \pm S E$ of proportion of mineral elements and $p H$ found in salt licking of common warthog in GCHA and HADCHA during the wet (w) and dry (d) seasons.

\begin{tabular}{lllll}
\hline Study site & Season & pH & OC & TN \\
\hline Miesso & w & $4.87 \pm 0.03$ & $1.95 \pm 0.08$ & $0.14 \pm 0.01$ \\
& d & $4.84 \pm 0.02$ & $1.8 \pm 0.54$ & $0.136 \pm 0.017$ \\
Seba & w & $4.98 \pm 0.14$ & $1.91 \pm 0.16$ & $0.193 \pm 0.023$ \\
& d & $4.72 \pm 0.18$ & $2.11 \pm 0.52$ & $0.141 \pm 0.02$ \\
Lemana & w & $5.11 \pm 0.04$ & $2.1 \pm 0.07$ & $0.17 \pm 0.004$ \\
& d & $4.8 \pm 0.44$ & $2.13 \pm 0.22$ & $0.125 \pm 0.014$ \\
Menjiko & W & $4.87 \pm 0.29$ & $2.10 \pm 0.07$ & $0.15 \pm 0.017$ \\
& d & $5.13 \pm 0.16$ & $2.71 \pm 0.06$ & $0.21 \pm 0.02$ \\
Robe & W & $5.15 \pm 0.04$ & $2.92 \pm 0.89$ & $0.129 \pm 0.09$ \\
& d & $4.23 \pm 0.01$ & $2.78 \pm 0.075$ & $0.19 \pm 0.005$ \\
Desa & W & $4.94 \pm 0.18$ & $2.38 \pm 0.43$ & $0.043 \pm 0.01$ \\
Gimbicho & w & $5.16 \pm 0.25$ & $2.94 \pm 0.08$ & $0.236 \pm 0.008$ \\
& d & $4.8 \pm 0.005$ & $1.91 \pm 0.39$ & $0.09 \pm 0.047$ \\
Dodeta & w & $4.34 \pm 0.06$ & $2.74 \pm 0.08$ & $0.17 \pm 0.002$ \\
& d & $5.34 \pm 0.41$ & $1.95 \pm 0.51$ & $0.175 \pm 0.02$ \\
\hline
\end{tabular}

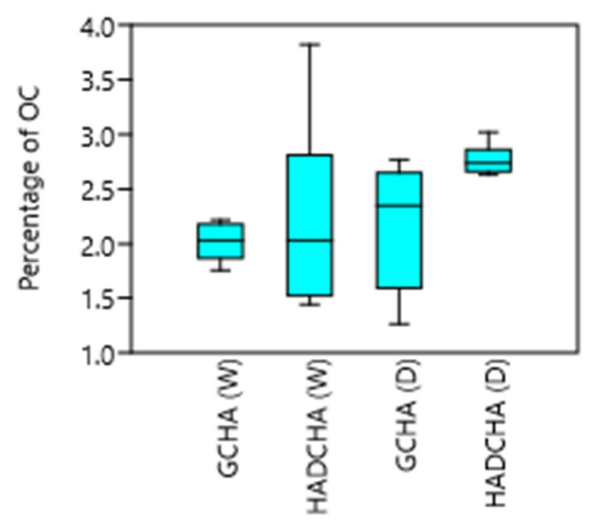

A. Study area and season

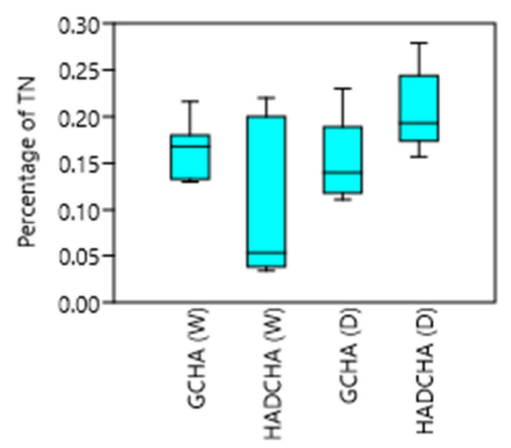

B. Study area and season

Figure 5. Percentage of organic carbon; $O C$ (A) and percentage total nitrogen; $T N(B)$ in the salt licking by common warthog in GCHA and $H A D C H A$.
During the wet season, the mean proportion of organic carbon in salt licking common warthog ingested was $2 \pm 0.05$ in GCHA and $2.29 \pm 0.59$ in HADCHA. But they were insignificantly different $\left(\mathrm{F}_{1,14}=0.94, \mathrm{P}>0.05\right)$. The mean proportion of organic carbon was less in GCHA $(2.19 \pm 0.19)$ and more in HADCHA $(2.78 \pm 0.04)$. They showed significant variation $\left(\mathrm{F}_{1,14}=9.08, \mathrm{P}<0.05\right)$ during the dry season (Figure $5 \mathrm{~A})$. The mean total nitrogen proportion in salt licking common warthog ingested was higher in GCHA $(1.32 \pm 0.16)$ and lower in HADCHA $(0.88 \pm 0.11)$ during the wet season. But they showed insignificant variation $\left(\mathrm{F}_{1,14}=3.67, \mathrm{P}>\right.$ 0.05). However, the mean proportion of total nitrogen was lower in GCHA $(0.153 \pm 0.014)$ and higher in HADCHA $(0.206 \pm 0.014)$ during the dry season. They showed significant variation $\left(\mathrm{F}_{1,14}=7.06, \mathrm{P}<0.05\right)$ in the amount of total nitrogen (Figure 5B).

The mean phosphorous concentration in salt licking common warthog ranged from $4.9 \pm 0.19 \mathrm{ppm}$ (Lemana) to $7.1 \pm 0.38 \mathrm{ppm}$ (Dodeta) during the wet season. Similarly, it varied from $2.95 \pm 0.17 \mathrm{P}$ ppm (Robe) to $13.9 \pm 8.82 \mathrm{P}$ ppm (Dodeta) during the dry season. Seasonal mean concentration of $\mathrm{P}$ in Seba $(\mathrm{t}=0.65, \mathrm{df}=1, \mathrm{P}>0.05)$, in Lemana $(\mathrm{t}=0.67, \mathrm{df}=1$, $\mathrm{P}>0.05)$, in Menjiko $(\mathrm{t}=0.82, \mathrm{df}=1, \mathrm{P}>0.05)$, in Desa $(\mathrm{t}=1.62$, $\mathrm{df}=1, \mathrm{P}>0.05)$, and in Dodeta $(\mathrm{t}=-0.78 \mathrm{df}=1, \mathrm{P}>0.05)$ did not show significant variation. In contrast, the mean concentration of $\mathrm{P}$ in Miesso $(\mathrm{t}=-3.57, \mathrm{df}=1, \mathrm{P}<0.05)$, in Robe $(\mathrm{t}=21.37, \mathrm{df}=1, \mathrm{P}<0.001)$, and in Gimbicho $(\mathrm{t}=-13.58$, $\mathrm{df}=1, \mathrm{P}<0.05)$ revealed significant variation between the wet and dry seasons (Table 2).

Potassium mean concentration in salt lick common warthog ranged from $0.11 \pm 0.014 \mathrm{meq} / 100 \mathrm{~g}$ (Desa) to $0.246 \pm 0.01$ $\mathrm{meq} / 100 \mathrm{~g}$ (Robe) during the wet season. Similarly, concentration varied from $0.047 \pm 0.003 \mathrm{~K}$ meq $/ 100 \mathrm{~g}$ (Gimbicho) to $0.32 \pm 0.06 \mathrm{~K}$ meq/100g (Menjiko) during the dry season. However, seasonal mean concentration of $\mathrm{K}$ in Miesso $(\mathrm{t}=1.25, \mathrm{df}=1, \mathrm{P}>0.05)$, in Seba $(\mathrm{t}=0.78, \mathrm{df}=1$, $\mathrm{P}>0.05)$, Lemana $(\mathrm{t}=1.14, \mathrm{df}=1, \mathrm{P}>0.05)$ and Dodeta $(\mathrm{t}=-1.66$, $\mathrm{df}=1, \mathrm{P}>0.05)$ did not show significant difference. The mean concentration of $\mathrm{K}$ in Menjiko $(\mathrm{t}=-3.04, \mathrm{df}=1, \mathrm{P}<0.05)$, Robe $(\mathrm{t}=24.43, \mathrm{df}=1, \mathrm{P}<0.001)$, Gimbicho $(\mathrm{t}=-3.72, \mathrm{df}=1, \mathrm{P}<0.01)$ and in Desa $(\mathrm{t}=2.53, \mathrm{df}=1, \mathrm{P}<0.05)$ revealed significant variation between the wet and dry seasons (Table 2).

The mean sodium concentration in salt lick common warthog varied from $0.012 \pm 0.002 \mathrm{meq} / 100 \mathrm{~g}$ (Dodeta) to $0.06 \pm 0.005 \mathrm{meq} / 100 \mathrm{~g}$ (Miesso) during the wet season. Likewise, the concentration ranged from $0.01 \pm 0.001 \mathrm{Na}$ meq/100g (Menjiko) to $0.08 \pm 0.006 \mathrm{meq} / 100 \mathrm{~g}$ (Dodeta) during the dry season. Seasonal mean concentration of $\mathrm{Na}$ in Seba $(\mathrm{t}=0.145, \mathrm{df}=1, \mathrm{P}>0.05)$, Menjiko $(\mathrm{t}=1.51, \mathrm{df}=1, \mathrm{P}>0.05)$, Robe $(\mathrm{t}=1.33, \mathrm{df}=1, \mathrm{P}>0.05)$, Desa $(\mathrm{t}=1.48, \mathrm{df}=1, \mathrm{P}>0.05)$, Gimbicho $(\mathrm{t}=0.75, \mathrm{df}=1, \mathrm{P}>0.05)$, and in Dodeta $(\mathrm{t}=-1.18$, $\mathrm{df}=1, \mathrm{P}>0.05)$ revealed insignificant variation. In contrast, the mean concentration of $\mathrm{Na}$ in Miesso $(\mathrm{t}=2.16, \mathrm{df}=1, \mathrm{P}<0.05)$ and in Lemana $(\mathrm{t}=2.04, \mathrm{df}=1, \mathrm{P}<0.001)$, showed significant variation between the wet and dry seasons (Table 2).

The mean magnesium concentration in salt lick common warthog ate varied from $0.15 \pm 0.064 \mathrm{meq} / 100 \mathrm{~g}$ (Miesso) to 
$0.93 \pm 0.09 \mathrm{meq} / 100 \mathrm{~g}$ (Robe) during the wet season. Similarly, the concentration ranged from $0.084 \pm 0.003 \mathrm{Mg}$ meq $/ 100 \mathrm{~g}$ (Gimbicho) to $2.39 \pm 0.24 \mathrm{meq} / 100 \mathrm{~g}$ (Desa) during the dry season. Seasonal mean concentration of $\mathrm{Mg}$ in Seba $(\mathrm{t}=-1.33$, $\mathrm{df}=1, \mathrm{P}>0.05)$, Menjiko $(\mathrm{t}=-0.79, \mathrm{df}=1, \mathrm{P}>0.05)$, Gimbicho $(\mathrm{t}=1.21, \mathrm{df}=1, \mathrm{P}>0.05)$, and in Dodeta $(\mathrm{t}=1.72, \mathrm{df}=1, \mathrm{P}>0.05)$ did not show significant variation between the wet and dry seasons. In contrast, the mean concentration of $\mathrm{Mg}$ in Miesso $(\mathrm{t}=-3.67, \mathrm{df}=1, \mathrm{P}<0.05)$ and in Lemana $(\mathrm{t}=-3.55, \mathrm{df}=1, \mathrm{P}<$ $0.05)$, in Robe $(\mathrm{t}=8.78, \mathrm{df}=1, \mathrm{P}<0.001)$ and in Desa $(\mathrm{t}=5.16$, $\mathrm{df}=1, \mathrm{P}<0.001$ ) showed significant differences between the wet and dry seasons (Table 2).

The mean calcium concentration in salt licking common warthog ranged from $0.63 \pm 0.17 \mathrm{meq} / 100 \mathrm{~g}$ (Miesso) to $3.84 \pm 0.64 \mathrm{meq} / 100 \mathrm{~g}$ (Lemana) during the wet season. Similarly, the concentration varied from $0.325 \pm 0.005 \mathrm{Ca}$ meq/100g (Gimbicho) to $4.55 \pm 1.04 \mathrm{meq} / 100 \mathrm{~g}$ (Desa) during the dry season. Seasonal mean concentration of $\mathrm{Ca}$ in Seba $(\mathrm{t}=-1.31, \mathrm{df}=1, \mathrm{P}>0.05)$, in Menjiko $(\mathrm{t}=-1.89, \mathrm{df}=1, \mathrm{P}>0.05)$, Robe $(\mathrm{t}=1.21, \mathrm{df}=1, \mathrm{P}>0.05)$, Gimbicho $(\mathrm{t}=1.3, \mathrm{df}=1, \mathrm{P}>$ $0.05)$ and in Dodeta $(\mathrm{t}=1.35, \mathrm{df}=1, \mathrm{P}>0.05)$ did not show significant difference between the wet and dry seasons. In contrast, the mean concentration of $\mathrm{Ca}$ in Miesso $(\mathrm{t}=-2.31$, $\mathrm{df}=1, \mathrm{P}<0.05)$ and in Lemana $(\mathrm{t}=3.74, \mathrm{df}=1, \mathrm{P}<0.05)$, and in Desa $(\mathrm{t}=2.02, \mathrm{df}=1, \mathrm{P}<0.05)$ revealed significant variation between the wet and dry seasons (Table 2).

Table 2. Concentration of mineral elements found in salt licking of common warthogs in GCHA and HADCHA during the wet (w) and dry (d) seasons.

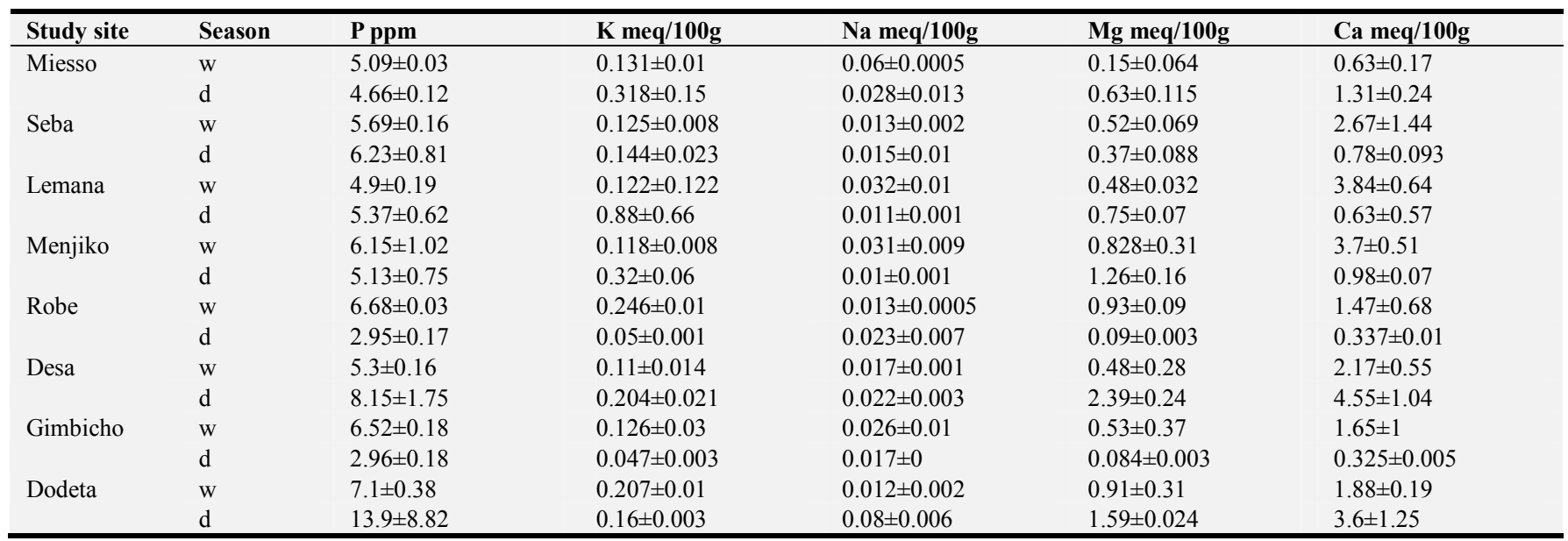

The mean $\mathrm{K}$ concentration in salt licking common warthog was less in GCHA $(0.122 \pm 0.005)$ and higher in HADCHA $(0.17 \pm 0.02)$ during the wet season. Thus, they showed significant variation $\left(\mathrm{F}_{1,14}=5.76, \mathrm{P}<0.05\right)$. During the dry season, the mean concentration of $\mathrm{K}$ was $0.41 \pm 0.17$ in GCHA and $0.11 \pm 0.026$ in HADCHA. But, the variation was insignificant $\left(\mathrm{F}_{1,14}=3.18, \mathrm{P}>0.05\right)$ (Figure 6A). During the wet season, the mean $\mathrm{P}$ concentration in salt licking common warthog was less in GCHA $(5.46 \pm 0.27)$ and high in HADCHA (6.4 \pm 2.41$)$. They showed significant difference $\left(\mathrm{F}_{1,14}=6.01, \mathrm{P}<0.05\right)$. During the dry season, the mean concentration of $\mathrm{P}$ was $5.34 \pm 0.32$ in GCHA and $6.99 \pm 2.41$ in HADCHA. Hence, they showed insignificant variation $\left(F_{1,14}=0.46, P>0.05\right)$ (Figure 6B).

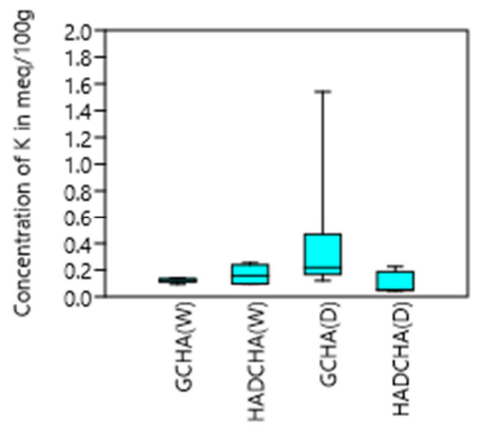

A. Study area and season

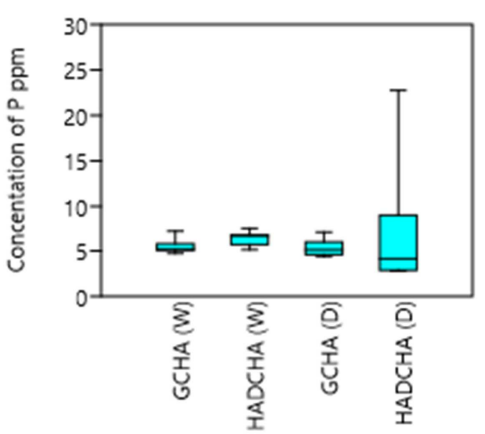

B. Study area and season

Figure 6. Percentage of $K(A)$ and percentage $P(B)$ in the salt licking by common warthog in GCHA and HADCHA.

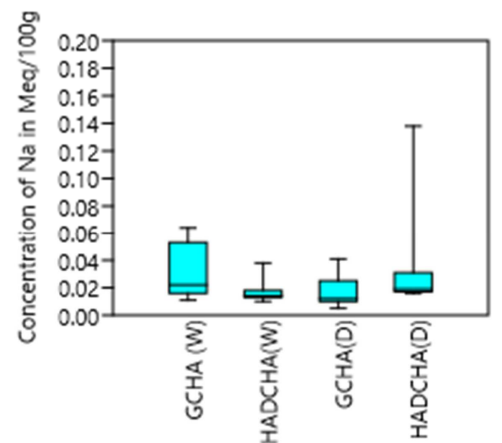

A. Study area and season 


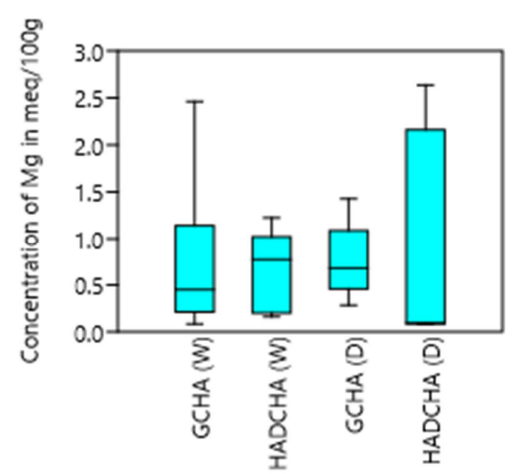

B. Study area and season

Figure 7. Percentage of $\mathrm{Na}(\mathrm{A})$ and percentage $\mathrm{Mg}(B)$ in the salt licking by common warthogs in GCHA and HADCHA.

The mean $\mathrm{Na}$ concentration in salt lick common warthogs was $0.033 \pm 0.006$ in GCHA and $0.017 \pm 0.003$ in HADCHA during the wet season. However, the variation was insignificant $\left(\mathrm{F}_{1,14}=4.43, \mathrm{P}>0.05\right)$. Likewise, during the dry season, the mean $\mathrm{Na}$ concentration was $0.016 \pm 0.004$ in GCHA and $0.035 \pm 0.014$ in HADCHA. But, they showed insignificant variation $\left(\mathrm{F}_{1,14}=1.63, \mathrm{P}>0.05\right)$ (Figure 7A).

The mean $\mathrm{Mg}$ concentration in salt licking common warthogs was $0.74 \pm 0.27$ in GCHA and $0.71 \pm 0.134$ in HADCHA during the wet season. However, they showed insignificant variation $(\mathrm{F} 1,14=0.005, \mathrm{P}>0.05)$. Similarly, during the dry season, the mean $\mathrm{Mg}$ concentration was 0.75 \pm 0.129 in GCHA and $1.04 \pm 0.38$ in HADCHA with insignificant variation $(\mathrm{F} 1,14=0.51, \mathrm{P}>0.05)$ (Figure $7 \mathrm{~B})$.

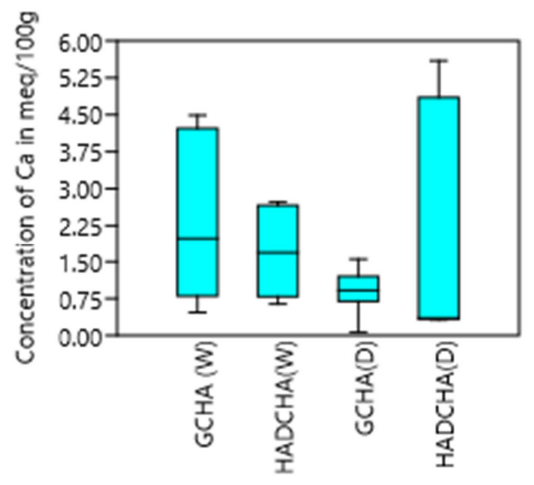

Study area and season

Figure 8. Concentration of $\mathrm{Ca}$ in the salt licking of common warthog in GCHA and HADCHA.

The mean Ca concentration in salt lick common warthog was $2.96 \pm 0.58$ in GCHA and $1.79 \pm 0.27$ in HADCHA during the wet season. However, they showed insignificant variation $\left(\mathrm{F}_{1,14}=1.44, \mathrm{P}>0.05\right)$. Likewise, during the dry season, the mean $\mathrm{Ca}$ concentration was $0.93 \pm 0.15$ in GCHA and $2.2 \pm 0.78$ in HADCHA. They showed insignificant variation $\left(\mathrm{F}_{1,14}=2.56, \mathrm{P}>0.05\right)$ (Figure 8).

\section{Discussion}

Salt or mineral lick influences the movements and distribution of ungulates $[7,14]$ and physiologically against intestinal ailments associated with forage phenology and serve to supplement mineral intake [7, 18]. It also maintains the equilibrium between the major minerals in the body of herbivorous mammals [18]. On the other hand, energetic costs to seek out mineral licks reduce time for foraging on vegetation [19]. Mineral elements are deficient in the diet of ungulates [7, 29]. Similarly, common warthogs and other ungulates regularly consume soil in African savannas for seeking different mineral elements to meet their nutritional requirements [24, 31]. Organic carbon buffers against disorders associated with wet season forage change, stabilizing $\mathrm{pH}$ in the stomach of ungulates and it is the main source of energy [5, 19]. Likewise, in the present study, common warthogs ingested comparable mean proportion of organic carbon salt lick in GCHA and in HADCHA during the wet season. During the dry season, the mean proportion of organic carbon was lower in GCHA and higher in HADCHA. This might be due to natural licks are special habitat features and site-specific to maintain the health of ungulate populations [7]. The finding of the present study showed differences from [32], who described $(\mathrm{OC}=1.2 \pm 0.3$ ) ingested by common warthogs in Mkwaja Ranch, Tanzania, was smaller than the finding of the present study.

During the present study, the mean total nitrogen proportion in salt licking common warthog ingested was higher in GCHA and less in HADCHA during the wet season. During the dry season, the mean proportion of total nitrogen was less in GCHA and higher in HADCHA. The finding of the present study was consistent with the finding of [32], who reported total nitrogen ingested by common warthog in Mkwaja Ranch in Tanzania. Phosphorous is one of the major mineral elements, which maintains an animal body [22]. In the present study, during the wet season the mean phosphorous concentration from salt lick common warthog ingested was less in GCHA and more in HADCHA. During the dry season, the mean concentration of phosphorous in GCHA and in HADCHA was comparable. This could be due to temporal and spatial patterns of licks visiting are different in the study areas and during season of year [26]. The finding of the present study was contradictory with [32], who found lower amount of phosphorous ingested by common warthog in Mkwaja Ranch in Tanzanian.

$\mathrm{Na}$ is a key driver of natural lick visitation [6]. During the dry season, grazing animals compensate for low $\mathrm{Na}$ concentration by visiting mineral springs, and saltimpregnated soils $[9,28]$. Thus, $\mathrm{Na}$ benefits ungulates in osmolarity regulation and compensate seasonal deficiencies in many forage plants [5]. In the present study, both study areas common warthogs ingested consistent meq/100g of $\mathrm{Na}$ in the salt lick during the wet and dry seasons. $\mathrm{K}$ ingested from earth licking elevates the osmotic pressure of the digestive tract and interferes with fecal water absorption. This leads to the loss of potentially harmful electrolyte and regulate acid-base equilibrium in animals [5, 27]. Hence, in the present study, the mean $\mathrm{K}$ concentration in salt lick common warthog was smaller in GCHA and greater in 
HADCHA. In contrast, during the dry season, the mean concentration of $\mathrm{K}$ ingested from the salt lick was similar in both study areas.

$\mathrm{Ca}$ and $\mathrm{Mg}$ are motivating factors of natural lick visitation [6]. However, they are extensively used by ungulates [5]. Ca is the major mineral constituent of the animal body [21]. $\mathrm{Mg}$ levels make the forage sub-optimal for maintaining animal growth and body condition [5]. In the present study, similar mean of $\mathrm{Mg}$ and $\mathrm{Ca}$ concentration were in salt lick by common warthog in GCHA and HADCHA during the wet the dry seasons. This might be due to even distribution of these mineral elements in Dabena Valley Forests.

\section{Conclusion}

Common warthogs population supplemented their forage intake by licking different mineral elements from the ground to meet their nutritional requirements. Chemical composition of lick soil ingested by common warthog comprised mainly, organic carbon, nitrogen, phosphorous, sodium, potassium, magnesium and calcium. Hence, organic carbon and phosphorous ingested by common warthog was higher in present study area. Total nitrogen ingested by warthog in the present study area was consistent with other range of the animal. These mineral licks benefits warthogs to compensate seasonal deficiencies of many forage plants in Dabena Valley Forests.

\section{Acknowledgements}

We are grateful to Addis Ababa University, Department of Zoological Sciences for financial support from thematic project. We are also indebted to Oromia Forest and Wildlife Enterprise for the permit provided to conduct this research in Dabena Valley Forest. We also thank our respondents and field assistants for their willingness and support during the period of data collection.

\section{References}

[1] Alemayehu Edossa, Afework Bekele, Habte Jebessa Debella 2020. Social Organization and Activity Patterns of Common Warthog (Phacochoerus africanus Gmelin, 1788) in Dabena Valley Forest, Western Ethiopia. Ecology and Evolutionary Biology, 5: 173-181. doi: 10.11648/j.eeb.20200504.18.

[2] Ali, Y. S. A. 2014. The impact of soil erosion in the upper Blue Nile on downstream reservoir sedimentation. $\mathrm{Ph} \mathrm{D}$ thesis submitted to Delft University of Technology and the academic board of the UNESCO-the Institute for water education. Pp. $1-190$.

[3] Augustine, D. J., Mcnaughton, S. J. and Frank, D. A. 2003. Feedbacks between soil nutrients and large herbivores in a managed savanna ecosystem. Ecol. Appl. 13: 1325-1337.

[4] Awulachew Bekele Seleshi, Aster Denekew Yilma, Mekonnen Loulseged, Loiskandl, W., Mekonnen Ayana and Tena Alamirew 2007. Water resources and irrigation development in Ethiopia. I. Wat. Manag. Inst. 123: 1-78.
[5] Ayotte, J. B. 2004. Ecological importance of licks to four ungulate species in North-central British Columbia. Mc. S. thesis submitted to the University of Northern British Columbia. 1-134.

[6] Ayotte, J. B., Parker, K. L., Arocena, J. M. and Gillingham, M. P. 2006. Chemical composition of lick soils: functions of soil ingestion by four ungulate species. J. Mamm. 87: 878-888.

[7] Ayotte, J. B., Parker, K. L., and Gillinghad, M. P. 2008. Use of natural licks by four species of ungulates in Northern British Columbia. J. Mammal. 89: 1041-1050.

[8] Azhar, B., Zakaria, M., Yusof, E. and Leong, P. C. 2008. Efficiency of fixed width transects and line transects based distance sampling to survey Red Jungle fowl (Gallus gallus spadiceus) in Peninsular Malaysia. J. Sust. Devel. 2: 63-73.

[9] Beck, J. L. and Peek, J. M. 2005. Great basin summer range forage quality: do plant nutrients meet elk requirements? $W . N$. Amer. Natur. 65: 516-527.

[10] Bekhuis, P. D. B. M., De Jong, C. B. and Prins, H. H. T. 2008. Diet selection and density estimates of forest buffalo in Campo-Ma'an National Park, Cameroon. Afr. J. Ecol. 46: 668-675.

[11] Betrie, G. D., Mohaded, Y. A., van Griensven, A. and Srinivasan, R. 2011. Sediment management modelling in the Blue Nile Basin using SWAT model. Hydrol. Eart. Syst. Sci. 15: 807-818.

[12] Chew, M. Y., Hymeir, K., Nosrat, R. and Shahfiz, M. A. 2014 Relation between grasses and large herbivores at the Ulu Muda salt licks, Peninsular Malaysia. J. Trop. For. Sci. 26: 554-559.

[13] Fitsum Merid 2002. National Nile Basin water quality monitoring baseline report for Ethiopia: Nile Basin initiative trans boundary environmental action project. Pp. 1-82.

[14] Gilmore, M. P., Griffiths, B. M. and Bowler, M. 2020. The socio-cultural significance of mineral licks to the Maijuna of the Peruvian Amazon: implications for the sustainable management of hunting. Journal of Ethnobiology and Ethnomedicine, 16: 59 https://doi.org/10.1186/s13002-020-00412-1

[15] Goheen, J. R., Palmer, T. M., Charles, G. K., Helgen, K. M. and Kinyua, S. N. 2013. Piecewise disassembly of a largeherbivore community across a rainfall. Plos one8: 1-16.

[16] Hon, J. and Shibata, S. 2013. Temporal partitioning by animals visiting salt licks. I. J. Envir. Sci. Devel. 4: 44-48.

[17] Jokinen, M. E., Verhage, M., Anderson, R. and Manzer, D. 2016. Frequency and timing ofuse of mineral licks by forest ungulates in southwest Alberta. Alb. Conser. Assoc. 101: 1-46.

[18] King, A., Behie, A. M., Hon, N. and Rawson, B. M. 2016. Patterns of salt lick use by mammals and birds in northeastern Cambodia. Camb. J. Nat. His. 1: 40-50.

[19] Klaus, G., Klaus-Hugi, C. and Schmid, B. 1998. Geophagy by large mammals at natural licks in the rain forest of the Dzanga National Park, Central African Republic. J. Trop. Ecol. 14: 829-839.

[20] Lameed, A. J. and Adetola, J. O. 2012. Species-diversity utilization of salt lick sites at Borgu Sector of Kainji Lake National Park, Nigeria. Biodiver. Enrich. Diver. Wor. 2: 3662. 
[21] Matsubayashi, H., Lagan, P., Majalap, N., Tangah, J., Rafiah, J., Sukor, A. and Kitayama, k. 2006. Importance of natural licks for the mammals in Bornean inland tropical rain forests. Ecol Res. 1-7. DOI 10.1007/s11284-006-0313-4.

[22] Montenegro, O. L. 2004. Natural licks as keystone resources for wildlife and people in Amazonia. $\mathrm{PhD}$ thesis submitted to University of Florida. Pp. 1-45.

[23] Nielsen, S. E., Johnson, C. J., Heard, D. C. and Boyce, M. S. 2005. Can models of presence/absence be used to scale abundance? Two case studies considering extremes in life history. Ecograph. 28: 197-208.

[24] Oliver, W. L. R. 1995. Taxonomy and conservation status of the suiformes: an overview. Ibex J. M. E. 3: 3-5.

[25] Panichev, A. M., Popov, V. K., Chekryzhov, I. Y., Seryodkin, I. V., Sergievich, A. A. and Golokhvast, K. S. 2017. Geological nature of mineral licks and the reasons forge geophagy among animals. Biogeosci. 14: 2767-2779.

[26] Ping, X., Li, C., Jianga, Z., Liuc, W. and Zhuc, H. 2011. Sexual difference in seasonal patterns of salt lick use by south China sika deer Cervus Nippon. Mamm. Biol. 76: 196-200.

[27] Poole, K. G., Bachmann, K. D. and Teske, I. E. 2010. Mineral lick use by GPS radio-collared mountain goats in Southeastern British Columbia. W. N. Amer. Nat. 70: 208-217.

[28] Ramachandran, K. K., Balagopalan, M. and Nair, V. 1995.
Use pattern and chemical characterization of the natural salt licks in Chinnar Wildlife Sanctuary. KFRI 94: 1-18.

[29] Sach F, Dierenfeld E. S, Langley-Evans, S. C, Watts, M. J, and Yon, L. 2019. African savanna elephants (Loxodonta africana) as an example of a herbivore making movement choices based on nutritional needs. Peer J, 1-27. 7:e6260 DOI $10.7717 /$ peerj. 6260

[30] Ritchie, M. E., Tilman, D. and Knops, J. M. H. 1998. Herbivore effects on plant and nitrogen dynamics in oak savanna. Ecol. Soci. Amer. 79: 165-177.

[31] Thorp, P. 2012. The influence of active bomas on habitat choice of the common warthog (Phacochoerus africanus). Skar. 1: 1-13.

[32] Treydte, A. C., Bernasconi, S. M., Kreuzer, M. and Edwards, P. J. 2006. Diet of the common warthog (phacochoerus africanus) on former cattle grounds in a Tanzanian Savanna. $J$. Mamm. 87: 889-898.

[33] van der Waal, C. 2010. Nutrients in an African Savanna: The consequences of supply heterogeneity for plants and animals. A thesis submitted in the fulfillment of the requirements for the degree of doctor at Wageningen University. Pp. 1-168.

[34] Wanyama, F., Muhabwe, R., Plumptre, A. J. and Chapman C. A. 2009. Censusing large mammals in Kibale National Park: evaluation of the intensity of sampling required to determine change. Afr. J. Ecol. 48: 953-961. 